\title{
Time to divest from the fossil-fuel industry
}

A s physicians, we are trained to respond to emergencies - the more serious the diagnosis, the more quickly we respond. Physicians, as guardians of human health, should be actively engaged in addressing the dangers of global warming, yet we are failing to act in a meaningful and substantive way. Fortunately, there are tools to help us act, including fossilfuel divestment, an idea similar to the divestment campaign of the 1980s that helped topple South African apartheid.

The idea of fossil-fuel divestment is based on what has been called the "terrifying new math."1 Global climate experts and governments have accepted the scientific consensus that an increase in global temperature must be held below two degrees celsius. To achieve this, scientists estimate that we must produce no more than 565 gigatonnes (Gt) of carbon dioxide. Current known fuel reserves, if burned, would represent 2795 Gt of carbon dioxide. This second number is a lot bigger than the first. If our planet is to survive, most of our current fuel reserves need to stay in the ground. Clearly, something needs to change.

Despite pledges from governments around the world to cut greenhouse gas emissions, most nations have consistently failed to meet their targets. Canada is among the worst offenders.

Expecting that fossil-fuel companies will voluntarily move in this direction, leaving their reserves untouched, is unjustified and naive. Corporations do what shareholders demand, and therein lies the key to divestment campaigns aimed at fossil-fuel companies. Proponents encourage concerned investors to withdraw their investments from coal, oil and gas companies, starting with a list of the 200 companies with the largest reserves, ${ }^{2}$ and then redirect their investments to industries that support a healthy climate future. This pressure will provide stimulus for fossil-fuel companies to transition to the production of more sustainable forms of energy; it allows them to become part

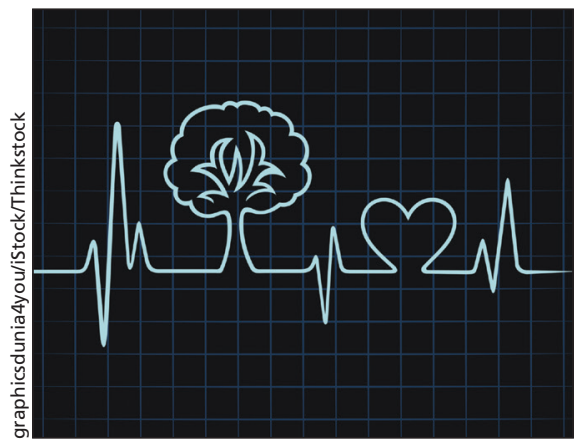

of the solution, building the healthy future that we all want.

Members of the British Medical Association recently voted to "transfer their investments from energy companies whose primary business relies upon fossil fuels to those providing renewable energy sources." 3 They are the first health organization to do so.

Some investors might fear that divestment could negatively affect their portfolios. On the contrary, many leading economists predict an imminent "carbon bubble," based on artificially inflated values of fossil-fuel-company stocks. ${ }^{4}$ This "bubble" arises from the inclusion of all the reserves that companies hold, without considering that these reserves can never be burned. This will leave companies with trillions in stranded assets. ${ }^{4}$ Even now, studies find that divested portfolios provide similar or better returns than their conventional counterparts. ${ }^{5}$

There may also be concerns that abandoning fossil-fuel resources in Canada could lead to economic collapse. In fact, the oil and gas industry accounts for only $5 \%$ of the Canadian economy. ${ }^{6}$ The latest United Nations Intergovernmental Panel on Climate Change (IPCC) report ${ }^{7}$ concluded that shifting hundreds of billions of dollars into renewable energy from fossil fuels and cutting energy waste would take only $0.06 \%$ off of our usual $1.3 \%-3.0 \%$ annual global economic growth. ${ }^{8}$ It has also been estimated that nonfossil-fuel industries create six to eight times as many jobs per dollar invested as fossil-fuel companies. ${ }^{9}$ Divestment for physicians is particularly important because we cannot, in good conscience, be strong advocates for addressing climate change while profiting from fossil-fuel companies. Many physicians have already made a commitment to divest from other unhealthy industries such as tobacco. Every Canadian physician can start by raising the issue with their investment adviser and encouraging their own university, hospital and medical society to divest from fossil fuels and reinvest in renewable-energy sources.

As physicians dedicated to promoting health, we can no longer sit at the bedside while our patient deteriorates. We have more than enough information to begin treatment now.

\section{Ilona Hale MD}

Family physician

Kimberly, BC

David Hale MSc Env Mgmt

Professional forester

Kimberly, BC

Courtney Howard MD

Emergency physician

Yellowknife, NT

Warren Bell MD

Family physician

Salmon Arm, BC

Editor's note: This article was originally posted as a Reflection on CMAJ Blogs (http://cmajblogs.com/)

\section{References}

1. McKibben B. Global warming's terrifying new math. New York (NY): Rolling Stone; 2012.

2. The world's top 200 public companies; Port Washington (NY): The Fossil Free Indexes; 2014.

3. Annual Representative Meeting agenda (ARM). London (UK): British Medical Association; 2014.

4. Wasted capital and stranded assets. London (UK): Carbon Tracker Initiative; 2014.

5. Extracting fossil fuels from your portfolio: a guide to personal divestment and reinvestment. Brooklyn (NY): 350.org; Boston (MA): Green Century Funds; Boston (MA): Trillium Asset Management; 2013.

6. The importance of crude oil. Ottawa $(\mathrm{ON})$ : Natural Resources Canada; 2013

7. Climate change 2014: mitigation of climate change. Geneva (Switzerland): Intergovernmental Panel on Climate Change; 2014.

8. Carrington D. IPCC climate change report: averting catastrophe is eminently affordable. London (UK): The Guardian; 2014

9. More bang for our buck: how Canada can create more energy jobs and less pollution. Toronto (ON): Bluegreen Canada; 2012.

CMAJ 2014. DOI:10.1503/cmaj.141008

All editorial matter in CMAJ represents the opinions of the authors and not necessarily those of the Canadian Medical Association. 